\title{
Quantitative Determination of Meprobamate by NMR in Commercial Preparations Marketed in Turkey ${ }^{1}$
}

\author{
Türkiyede Satılan İlaçlarda NMR ile Meprobamat Miktar Tayini ${ }^{1}$
}

\author{
Ningur NOYANALPAN* Tuncel ÖZDEN*
}

\section{INTRODUCTION}

Oualitative and quantitative analysis of the compounds and mixtures of complicated structure requires easier and more accurate, rapid methods. The first use of NMR spectrometry for the quantitative determination of Meprobamate has been realized by TURCZAN and $\mathrm{KRAM}^{2}$. This method has many superiorities such as rapidity, specificity, producing more accurate results, and also the additives and other active ingredients of the drug (i.e. amfetamine, chlorothiazides, dexamethasone, aspirin, pentaerithrytol etc.) do not effect the determination. Moreover, the standard error is allways within the limits of $1-1,5 \%$ which is unattainable with any other method recognised today. From the qualitative point, the spectrum provides an identification of the ingredient.

Generally the quantitative determination of meprobamate in drugs are assumed with a method mentioned in the NF $\mathrm{XII}^{3}$ and a gravimetric one. The gravimetric method also used in Turkey is based on the extraction of meprobamete with acetone then evaporation of the latter and weighing the residue. With this method, correct result is very susceptible if another acetone souluble ingredient is present in the drug, e.g. pentaerithrytol present in Equanitrate ${ }^{\mathbf{R}}$ tablets makes it impossible to use gravimetric method due to solubulity in

Redaksiyona verildiği tarih: 26 Aralık 1977.

* Farmasötik Kimya Kürüsü, Eczacılık Fakültesi, Ankara Úniversitesi. 
acetone. In such a case a modification is carried out according to $\mathrm{NF} \mathrm{XII}^{3}$ and after the extraction of meprobamate with acetone, an acid solvolysis is performed followed by titration with standard sodium hydroxide solution in presence of formol. This method is more time consuming and less specific then NMR spectrometric method. Other methods that are used in the quantitative determination of meprobamate are steam distillation ${ }^{4}$, color reactions ${ }^{5,6}$ and IR specrophotometric methods ${ }^{6}$.

NMR method is far superior to those methods as mentioned above in respect of rapidity, speeficity and easiness.

In this research the method established by TURCZAN and $\mathrm{KRAM}^{2}$ has been applied to meprobamate preparations marketed in Turkey,

\section{EXPERIMENTAL PART \\ METHOD}

In their research about the quantitative determination of meprobamate by NMR spectrometry, TURCZAN and $\mathrm{KRAM}^{2}$ have used the characteristic signal of two equalent methylene qroups which are $\alpha$ to quaternary carbon atom and compared this siqnal at $3.83 \mathrm{ppm}$ with the signal of methylene group of malonic acid at 3.40 ppm.

On the $60 \mathrm{MHz}$ NMR spectrum of meprobamate (Spectrum-1) the signals are identified as, 4 protons of amide groups at $5.83 \mathrm{ppm}$, (d), 4 protons of the two methylene groups attached to oxygenes (c) at $3.83 \mathrm{ppm}, 4$ protons of two metyhlene groups at alifatic side chain (b) at $1.27 \mathrm{ppm}$, and 6 protons of two methyl groups sitting at the and of alifatic chain (a) at $0.90 \mathrm{ppm}$.

On the $60 \mathrm{MHz}$ NMR spectrum of malonic acid (Spectrum-2) the signals are identified as, 2 protons of methylene group (a) at 3.40 ppm and 2 protons of carboxyl groups (b) at $11.15 \mathrm{ppm}$. As it is evident from the explanation above, two singlets each belonging te malonic acid and meprobamate could have deen compared for the quantitative determination.

\section{EXPERIMENTS}

Ten tablets or any other form of meprobamete preparations are weighed and ground to fine powder. From this powder a cer- 


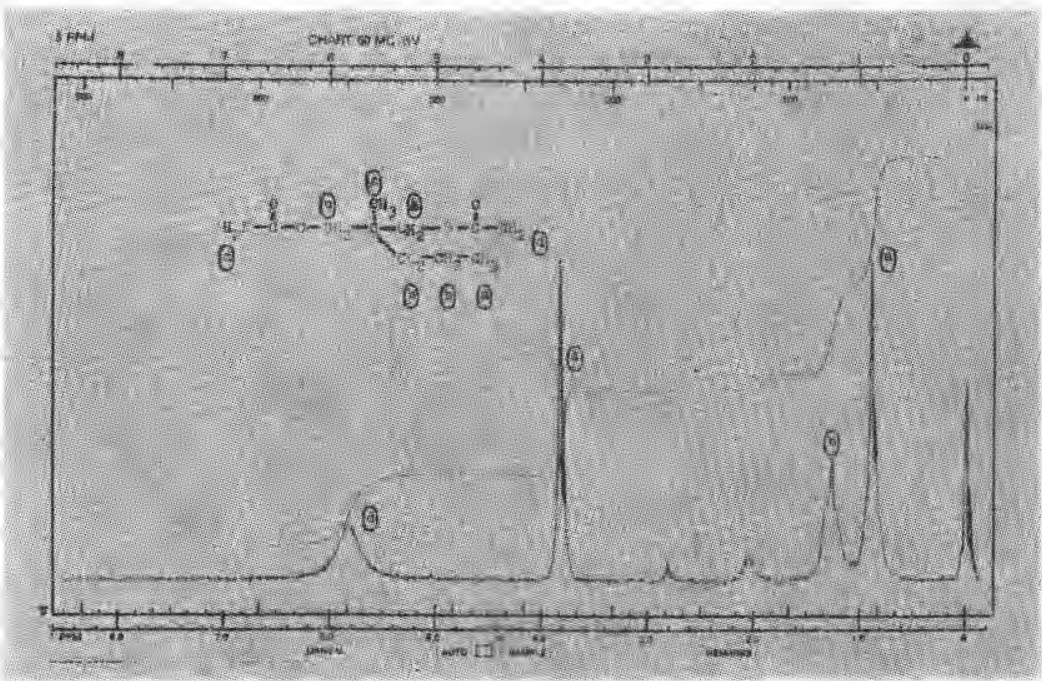

Spectr 1. $60 \mathrm{MHz}$ NMR spectrum of Meprobamate

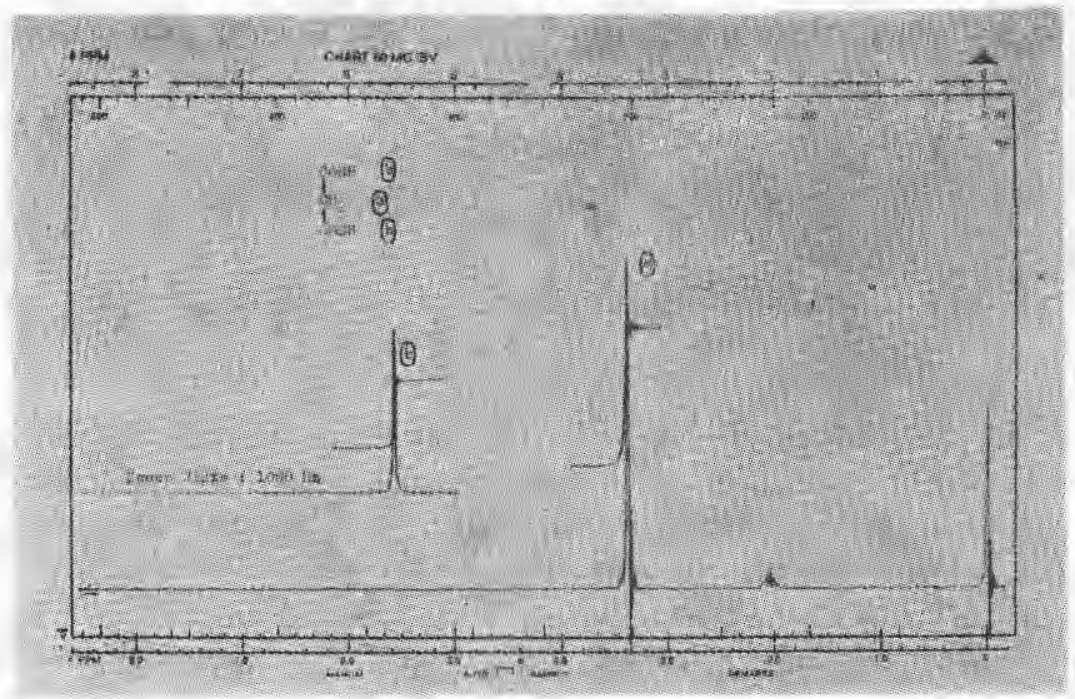

Spectr 2. $60 \mathrm{MHz}$ NMR spectrum of Malonic acid.

tain portion corresponding theoretically to $400 \mathrm{mg}$ meprobamate is weighed accurately and taken into centrifuge tube. To this tube $400 \mathrm{mg}$ of malonic acid accurately weighed is added. Then whole mixture is stirred adequately with $5 \mathrm{ml}$ of deuterated acetone and 
centrifuged. A spectrum is drawn with $0.4-0.5 \mathrm{ml}$ of the clear supernatant layer. Meanwhile spinning of the tube is adjusted at such a rate that particulary the spinning sideebands at $3.10 \mathrm{ppm}$ and 4.00 ppm can be removed. Later on the integrals of the signals at $3.40 \mathrm{ppm}$ and $3.83 \mathrm{ppm}$ are drawn repeatedly (Spectrum-3).

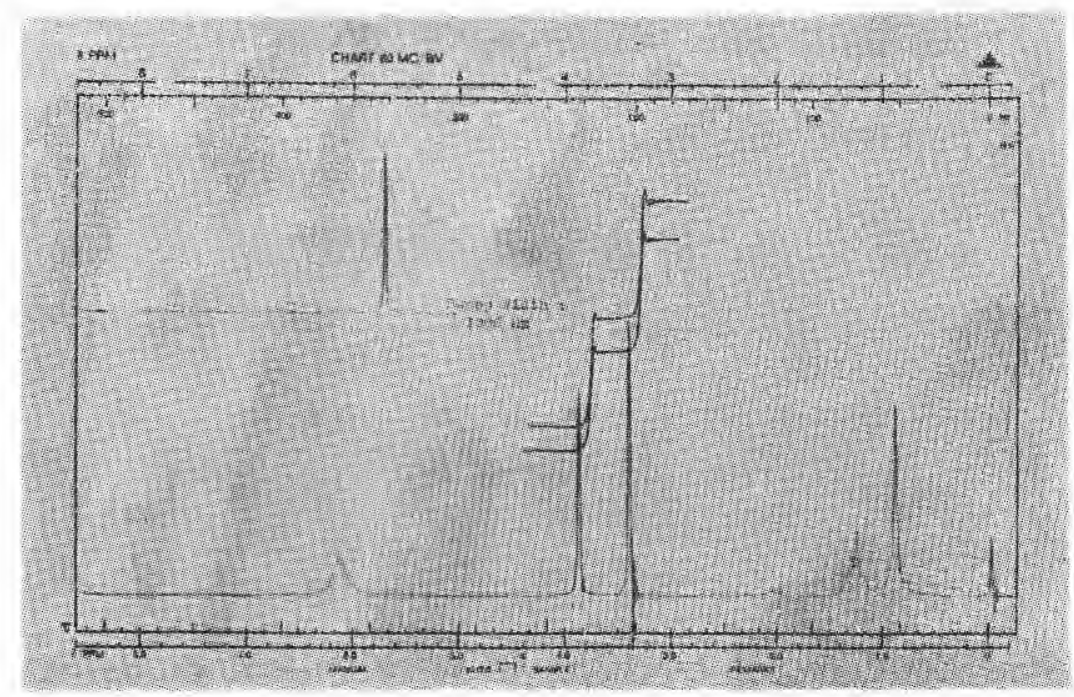

Spectr 3. $60 \mathrm{MHz}$ NME spectrum of Malonic acid and Meprobamate mixture.

In addition to the quantitative determination given above a qualitative result can also be considered looking at the characteristic signaclusters of meprobamate between $0.80 \mathrm{ppm}$ and $1.40 \mathrm{ppm}$. In routine studies there is no obligation to work with deuterated acetone because it's C-13 satellite signal at $3.00 \mathrm{ppm}$ does not interfere with the high field portion of meprobamate. In this research also spectrophotometric grade acetone has been used along with the deuterated one and similar results have been produced.

For gravimetric determinations usual method has been applied by grinding not less then twenty tablets, extracting with acetone and by weighing the residue after filtration and evaporation of the acetone solution. 
For the quantitative determination mentioned in the NF $\mathrm{XII}^{3}$, an acid solvolysis followed by alkali titration in presence of formol has beeen applied, after acetone extraction and evaporation.

\section{RESULTS and DISCUSSION}

The quantity of meprobamate in each tablet is calculated according to the equation given below:

$\frac{\text { Meprobamate in } \mathrm{mg}}{\text { number of tablets }}=\frac{\text { IMepro. }}{\text { IMal.ac. }} \times \frac{\text { NMepro }}{\text { NMal.Ac. }} \times$ quantity of $\mathrm{Mal}$, ac, added on

IMepro. : the average height of integral signal at $3.83 \mathrm{ppm}$

IMal.ac. : the average height of integral signal et $3.40 \mathrm{ppm}$

NMepro. $: \frac{\text { Molecular weight of Meprobamate }}{\text { number of protons giving signal at } 3.83 \mathrm{ppm}}=\frac{218.24}{4}=54.56$

NMal.ac. $=\frac{\text { Molecular weight of Mal.ac. }}{\text { number of protons giving signal at } 3.40 \mathrm{ppm}}=\frac{104.06}{2}=52.03$

With this procedure using the equations given above, meprobamate contents of the drugs marketed in Turkey have been determined. The results of NMR spectrometric dererminations along with the results of gravimetric method and the results according to the method of NF XII are given in Table-I.

\section{SUMMARY}

In this research quantitative NMR spectrometric determinations of Meprobamate in twelve commercial preparations marketed in Turkey have been studied. The results of the determinations have ben documented in a table and compared with those obtained from gravimetric and NF XII's titrimetric methods. This method has been found more rapid, producing more accurate results and more specific then other quantitative determination methods.

\section{ÖZET}

Bu çăı̧̧mada, Türkiyede satılan oniki ilacın içindeki Meprobamat niceliği NMR spektrometri ile saptanmıştır. Bu saptamaların sonuçları bir çizelge şeklinde dökümlenmiş ve hem gravimetrik hem. de NF XII nin vermiş olduğu yöntemle varılan sonuçlarla karşılaş- 
Table I. The amounts found and \% errors

\begin{tabular}{|c|c|c|c|c|c|c|c|}
\hline Drug name ${ }^{\mathbf{R}}$ & $\begin{array}{l}\text { given theoretical } \\
\text { amount of Mepro. }\end{array}$ & NMR & $\%$ error & Grav. & $\%$ error & NF XII & $\%$ error \\
\hline $\begin{array}{l}\text { Equanitrate } \\
\text { Equanil } \\
\text { Mekuadon } \\
\text { Meprobamat (Ordu } \\
\text { İlaç Fab.) } \\
\text { Meprol } \\
\text { Mepromin } \\
\text { Meprosedine } \\
\text { Mergal } \\
\text { Miltown } \\
\text { Pertrankil } \\
\text { Relaksin } \\
\text { Trankilin }\end{array}$ & $\begin{array}{l}200 \\
400 \\
400 \\
\\
400 \\
400 \\
400 \\
100 \\
250 \\
400 \\
400 \\
400 \\
400\end{array}$ & $\begin{array}{r}197.8 \\
396.8 \\
395.6 \\
396.0 \\
395.6 \\
396.2 \\
98.9 \\
247.2 \\
395.3 \\
395.6 \\
395.3 \\
395.4 \\
\end{array}$ & $\begin{array}{l}1.10 \\
0.80 \\
1.10 \\
1.00 \\
1.10 \\
0.95 \\
1.10 \\
1.12 \\
1.17 \\
1.10 \\
1.17 \\
1.15\end{array}$ & $\begin{array}{l}\overline{379} \\
381 \\
384 \\
382 \\
384 \\
97 \\
238 \\
392 \\
380 \\
378 \\
383.8\end{array}$ & $\begin{array}{l}-\overline{5.25} \\
4.75 \\
4.0 \\
4.5 \\
4.0 \\
3.0 \\
6.0 \\
2.0 \\
5.0 \\
5.5 \\
4.05 \\
\end{array}$ & $\begin{array}{r}188 \\
368 \\
380 \\
\\
372 \\
380 \\
388 \\
94 \\
237 \\
384 \\
372 \\
380 \\
380 \\
\end{array}$ & $\begin{array}{l}6 \\
8 \\
5 \\
7 \\
5 \\
3 \\
6 \\
6.5 \\
4 \\
7 \\
5 \\
5 \\
\end{array}$ \\
\hline
\end{tabular}


tırılmıştır. Bu yöntemin daha çabuk olduğu, daha doğru sonuçlar verdiği ve diğer yöntemlerden daha özel olduğu ortaya konulmuştur.

\section{REFERENGES}

1. For previous paper see: Noyanalpan, N., Özden, T.: F.Fac.Pharm. Ankara 7, 96 (1977).

2. Turczan, J.W., and Kram, T.C.: : F.Pharm. Sci. 56, 1643 (1967).

3. "National Formulary", 12th ed., Mack Publishing Co., Easton, Pa., p. 238. 1965.

4. Harris, E.S., and Reik, J.J., Clin. Chem., 4, 241 (1958).

5. Sasaki, S., Mori, H., and Ichimura, S., Yakugaku Zasshi, 78, 1185 (1958).

6. Maggiorelli, E., Farmaco (Pavia), Ed, Prat., 13, 656 (1958). 